\title{
Patterns of avian diversification in Borneo: The case of the endemic Mountain Black-eye (Chlorocharis emiliae)
}

\author{
Dency F. Gawin, ${ }^{1,2 *}$ Mustafa Abdul Rahman, ${ }^{2}$ Mohamad Fizl Sidq Ramji, ${ }^{2}$ Brian Tilston Smith, ${ }^{1}$ Haw Chuan \\ Lim, ${ }^{1}$ Robert G. Moyle, ${ }^{3}$ and Frederick H. Sheldon ${ }^{1}$ \\ ${ }^{1}$ Museum of Natural Science and Department of Biological Sciences, Louisiana State University, Baton Rouge, Louisiana, USA \\ ${ }^{2}$ Faculty of Resource Science and Technology, Universiti Malaysia Sarawak, Sarawak, Malaysia \\ ${ }^{3}$ Biodiversity Institute and Department of Ecology and Evolutionary Biology, University of Kansas, Lawrence, Kansas, USA \\ * Corresponding author: dgawin1@tigers.Isu.edu
}

Received September 21, 2013; Accepted November 16, 2013; Published January 22, 2014

\begin{abstract}
The Mountain Black-eye (Chlorocharis emiliae) is an endemic white-eye (Zosteropidae) of Borneo with a unique "sky island" distribution. We compared mitochondrial ND2, ND3, Cytb, and control region DNA sequences (2,194 nucleotides) to study the phylogeographic relationships of five populations of this species that span its range: Mounts Kinabalu, Trus Madi, Murud, Mulu, and Pueh. These comparisons showed that black-eyes are divided into two main clades that correspond generally to subspecific morphological groups: one in Sabah, Malaysia (Kinabalu and Trus Madi), and one in Sarawak, Malaysia (Murud, Mulu, and Pueh). The genetic and morphologic subdivision of black-eyes disputes the expected merging of populations during the Last Glacial Maximum (LGM), when montane forest presumably expanded and provided the opportunity for currently isolated populations to intermingle. Instead the genetic aging of black-eye populations indicates they diversified long before the LGM, and either did not expand sufficiently in range during the LGM to reach one another, or were reproductively isolated by the time of the LGM and thus prevented from interbreeding. Moreover, the subdivision between black-eyes in Sabah and Sarawak means that this species (and probably several other montane species) has a phylogeographic structure remarkably similar to Borneo's lowland bird populations, which are presumed to have evolved under different paleo-geographic conditions. The similar phylogeographic pattern found in both montane and lowland species requires that we rethink the causes of bird population diversification on the island of Borneo.
\end{abstract}

Keywords: Greater Sunda Islands, last glacial maximum, montane avifauna, phylogeography, refugia, sky islands, Zosteropidae

\section{Patrons de diversification aviaire à Bornéo: Le cas d'une espèce endémique, Chlorocharis emiliae \\ RÉSUMÉ}

Chlorocharis emiliae est une espèce endémique de Zosteropidae de Bornéo ayant une répartition unique de type "sky island." Nous avons comparé les séquences d'ADN mitochondrial ND2, ND3, Cytb, et de la région de contrôle (2,194 nucléotides) afin d'étudier les relations phylogéographiques de cinq populations de cette espèce qui couvrent toute son aire de répartition: Les Monts Kinabalu, Trus Madi, Murud, Mulu, et Pueh. Ces comparaisons ont montré que C. emiliae se divise en deux principaux clades qui correspondent généralement aux groupes morphologiques sousspécifiques: un à Sabah, en Malaisie (Kinabalu et Trus Madi) et un à Sarawak, en Malaisie (Murud, Mulu, et Pueh). La subdivision génétique et morphologique de $C$. emiliae conteste I'hypothèse de fusion des populations au cours du dernier maximum glaciaire (DMG), lorsque la forêt montagnarde s'est vraisemblablement développée et a fourni aux populations actuellement isolées l'occasion de se mélanger. Au lieu de cela, le vieillissement génétique des populations de C. emiliae indique qu'elles se sont diversifiées bien avant le DMG, et que leur aire de répartition ne s'est pas suffisamment élargie au cours du DMG pour se rejoindre, ou encore qu'elles étaient isolées sur le plan de la reproduction au moment du DMG, empêchant ainsi les croisements. Par ailleurs, la subdivision entre $C$. emiliae à Sabah et Sarawak signifie que cette espèce (et probablement plusieurs autres espèces montagnardes) possède une structure phylogéographique remarquablement similaire à celle des populations d'oiseaux des basses terres de Bornéo, que l'on croit avoir évolué sous différentes conditions paléo-géographiques. Le patron phylogéographique similaire trouvé à la fois chez les espèces montagnardes et des basses terres nécessite que nous repensions les causes de la diversification des populations d'oiseaux sur l'île de Bornéo.

Mots-clés: Grandes Îles de la Sonde, dernier maximum glaciaire, avifaune montagnarde, phylogéographie, refuge, sky islands, Zosteropidae 


\section{INTRODUCTION}

The island of Borneo is well-known for the diversity and endemicity of its avian species, especially in montane areas (Whitehead 1893, Smythies 1999). Including recent taxonomic revisions, 51 endemic species are now recognized on the island, 36 of which are montane or hill slope specialists (Mann 2008, Myers 2009, Phillipps and Phillipps 2011). In general, Borneo's montane endemics are found above $1,200-1,400 \mathrm{~m}$ throughout the island's main mountain range, which runs southwest from Mt. Kinabalu in the extreme northeast and dominates the central part of the island (Figure 1). Many of these endemics also reach isolated peaks well away from the main range. A few species, however, have highly restricted or peculiar distributions. The Friendly Bush Warbler (Locustella [Bradypterus] accentor), for example, occurs only on the three Bornean mountains that rise above 2,500 $\mathrm{m}$ in elevation, and the Mountain Black-eye (Chlorocharis emiliae Sharpe 1888) occurs mainly above $1,800 \mathrm{~m}$ on isolated peaks, but also on a few outlying, lower-elevation mountains. Recent phylogenetic studies of Bornean montane endemics-viz., Bornean Swiftlet (Collocalia dodgei), Whitehead's Trogon (Harpactes whiteheadi), Whitehead's Spiderhunter (Arachnothera juliae), Bornean Forktail (Enicurus borneensis), Fruithunter (Chlamydochaera jefferyi), Pygmy White-eye (Oculocincta squamifrons), Bornean Stubtail (Urosphena whiteheadi), and Mountain Black-eye-have shown that the sister taxon of each resides on islands other than Borneo, especially Java and the Philippines (Klicka et al. 2005, Moyle et al. 2005, Moyle et al. 2008, Moyle et al. 2009, Hosner et al. 2010, Alström et al. 2011, Moyle et al. 2011). But other studies have found (Moyle et al. 2011) or suggested (Moltesen et al. 2012, den Tex and Leonard 2013) the opposite, that some Bornean montane endemics-specifically the barbets Megalaima eximia, M. monticola, and M. pulcherrima; Bornean Spiderhunter (A. everetti); and Bornean Leafbird (Chloropsis kinabaluensis)-are more closely related to congeners in the Bornean lowlands than to congeners on other islands. Such biogeographic patterns and anomalies have intrigued avian biogeographers since extensive exploration of the interior mountains of Borneo began in the 1920s (Banks 1937, Harrisson 1949, 1955b, Smythies 1957, 1960, Sheldon et al. 2001, Sheldon et al. 2013). As our knowledge has grown, so has the observed variation in biogeographic patterns. It is now evident that a multitude of evolutionary forces shaped the montane avifauna of Borneo.

The distribution of Bornean mountain birds has almost certainly been influenced by climatic fluctuations associated with global glacial cycles. During periods of global cooling and glaciation, sea levels fall, land area increases, and oceanic effects are moderated. The general influence

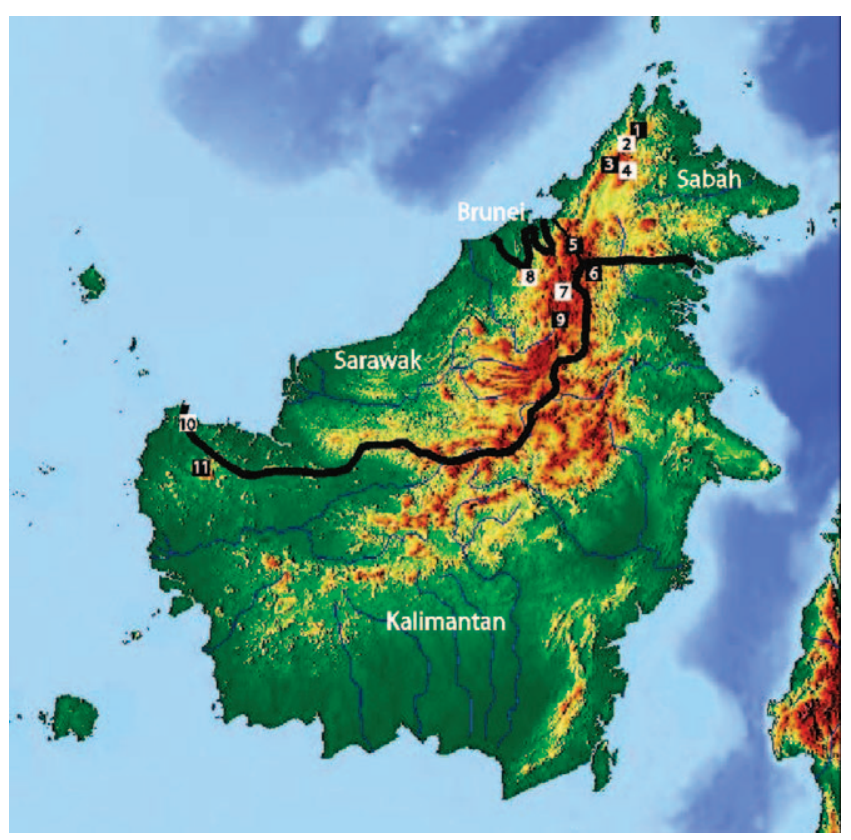

FIGURE 1. The known distribution of Mountain Black-eye populations: 1 Tambuyukon, 2 Kinabalu, 3 Alab, 4 Trus Madi, 5 Paya Maga (exact position uncertain), 6 Harun, 7 Murud, 8 Mulu, 9 Tama Abo, 10 Pueh, and 11 Nyiut. Filled black squares indicate populations not examined in this study. Heavy black lines mark international borders. The thinner line marks the Sabah-Sarawak border. Map from www.maps-for-free.com

of glacial cycles on the Greater Sunda Islands (Borneo, Sumatra, and Java) is well-known; the Sunda continental shelf was periodically exposed and submerged, thereby connecting and disconnecting the islands with one another and the Asian mainland (Hanebuth et al. 2000, Voris 2000, Bird et al. 2005, Cannon et al. 2009). Shifts in global temperatures may have also caused the elevational distributions of the montane forests of Sundaland to rise and fall (Morley 2000, Cannon et al. 2009). Pollen data from Sumatra and Java show that montane forest descended from approximately $1,700-2,400 \mathrm{~m}$ to $1,200-$ $1,500 \mathrm{~m}$ during the last glacial maximum (LGM) about 23,000-19,000 years ago (figure 4 in Flenley 1998, figure 9.30 in Morley 2000). Some models that incorporate these and other paleontological data with geographic and climatic data suggest the possibility that during the LGM much of central Borneo consisted of montane and submontane evergreen forest (Figure 2). The lowerelevation rainforest that currently covers the island was relegated to the fringes of modern-day Borneo and to the large area of continental shelf presently under the South China Sea (Cannon et al. 2009). Dramatic shifts in position and types of habitat would have occurred in each of the Quaternary glacial cycles, including eight in the last 740,000 years (Augustin et al. 2004), creating an extremely complex biogeographic history. Expansion of Borneo's 

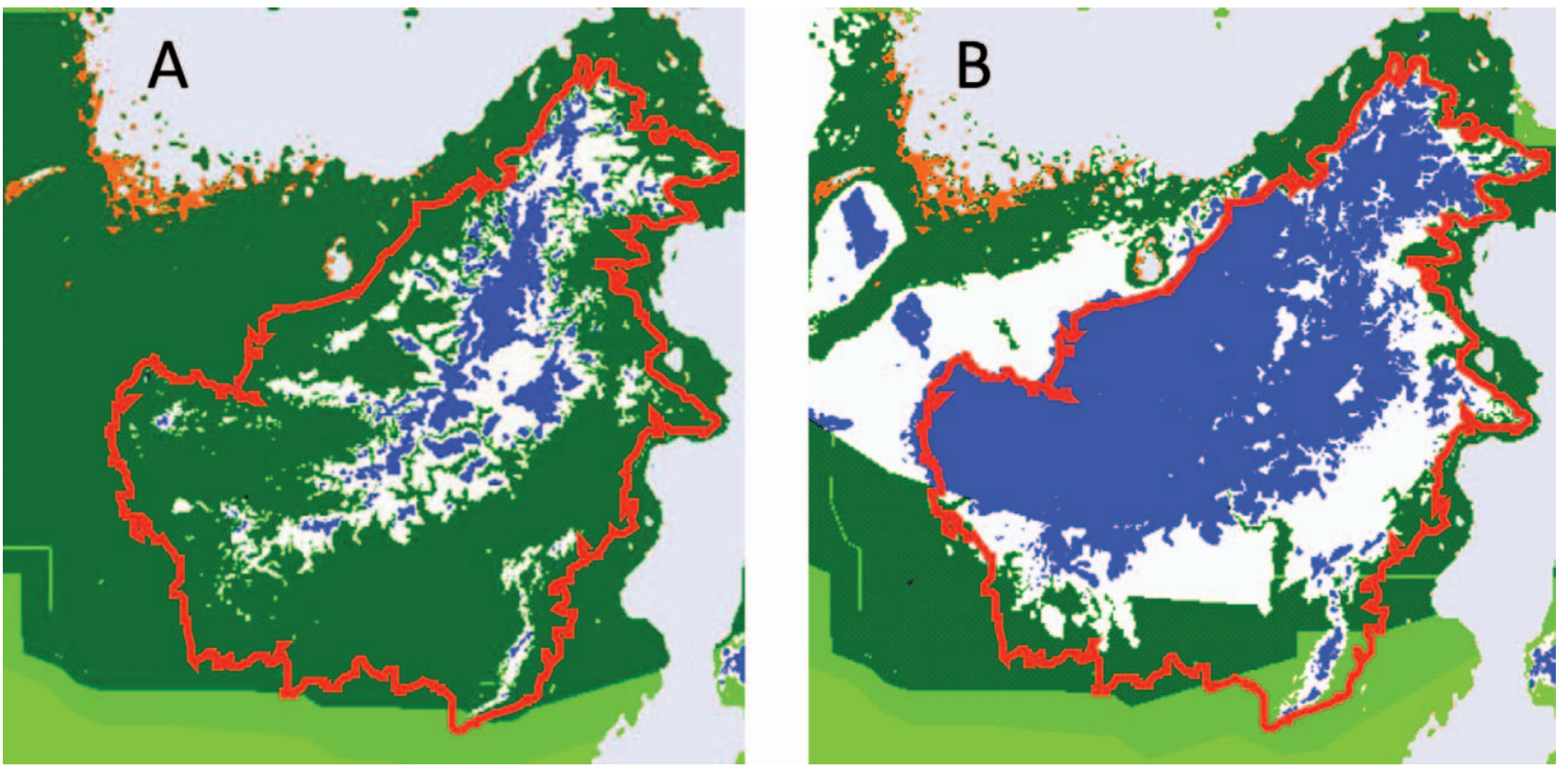

FIGURE 2. Model-based representation of habitats at the Last Glacial Maximum from Cannon et al. (2009) with the current coastline of Borneo added in orange. (A) Scenario in which the spread of lowland rainforest is maximal and montane forest minimal. (B) Represents the opposite scenario. Dark green is lowland rainforest, blue is montane rainforest, white is transitional hill forest, and orange is mangrove. (Figure reproduced with author's permission.)

montane forest during glacial cycles would explain how birds of the central range reached isolated mountains. The increased connectivity among montane sites would be expected to homogenize previously isolated populations through gene flow. The combination of land connections between islands and expanded montane forest would also increase the likelihood of montane bird dispersal among major islands.

The Mountain Black-eye is an unusual montane endemic of Borneo. It is a typical white-eye of the family Zosteropidae (Hartert 1897, Finsch 1901, Moyle et al. 2009), but unlike the other white-eyes it has a black eyering. Its range is divided into disjunct sky-island populations, producing a distribution unique among Bornean birds. Most populations occur on Borneo's highest peaks $(>2,000 \mathrm{~m})$, but two populations are found on isolated, lower elevation mountains (Figure 1). Specifically, blackeyes are known from Mt. Tambuyukon $(2,580 \mathrm{~m})$, Mt. Kinabalu (4,095 m), Mt. Trus Madi (2,642 m), and Mt. Alab $(2,085 \mathrm{~m})$ in northern Sabah, Malaysia; Mt. Harun (=Arun, 1,998 m) in Kayan-Mentarang National Park, East Kalimantan, Indonesia, near the Sabah-Sarawak border; Mt. Mulu (2,376 m), Mt. Murud (2,423 m), and in the Tama Abo Range, which extends southward from Murud, in northern Sarawak, Malaysia; Mt. Pueh (=Poi, 1,552 m) in an isolated range in western Sarawak; and Mt. Nyiut (=Niut, 1,701 m) in northwestern Kalimantan, Indonesia (Banks 1952, Preme and Heegaard 1988, Smythies 1999, Sebastian 2007, Wong 2010, Ramji et al. 2012a). The location of one population-the type locality of subspecies C. e. fusciceps-is uncertain. This population is known from only two specimens collected by E. Banks of the Sarawak Museum on May 1, 1939. The collecting site is usually placed in the Maga Mountains (or Paya Maga Highlands) along the Sabah-Sarawak border (Smythies 1999), where there is a $1,400 \mathrm{~m}$ plateau and a high point of 1,860 m (Mt. Matalan). Harrisson (1955a), however, claimed that the collecting site could be anywhere in the Sabah-Sarawak border region. The specimens are labeled "Ulu Maga, Trusan" and "5821 feet" $(=1,774 \mathrm{~m})$, the Sarawak Museum catalogue has them from "Ulu Trusan" (Harrisson 1955a), and the type locality is described as "Pak Maga, Ulu Trusan," NE Sarawak, $4^{\circ} 20^{\prime} \mathrm{N} 115^{\circ} 50^{\prime} \mathrm{E}$ (Mees 1954). These coordinates place the collecting site near Muruk Miau, Sabah (2,083 m in elevation), relatively far from Paya Maga and nearer Mt. Harun.

The life history and ecology of black-eyes is not wellknown beyond their general habitat requirements. They occur in upper montane forest, i.e. the wet, stunted, dense elfin or mossy forest associated with Borneo's highest peaks and ridges (Harrisson 1955a, Davison 1992, Smythies 1999). Such forest generally replaces lower montane forest at about $1,800 \mathrm{~m}$ on large mountains and in mountain chains, but may occur at lower elevations on isolated mountains (Grubb and Whitmore 1966, Whitmore 1984). From our experience, black-eye populations are also always associated with (if not always in) the ericaceous alpine meadow ("taman bunga") that occurs 
above the tree line or on exposed ridges and peaks. The birds are extremely common in this heath scrub, and it is a likely requirement for their nesting (Harrisson 1955a, Smythies 1999). Although most abundant at high elevation, black-eyes also forage in the canopy of forest at lower elevations, down to $1,500 \mathrm{~m}$ on Mts. Kinabalu and Trus Madi, especially during dry periods (Smythies 1999, Sheldon et al. 2001). Their elevational range on other mountains is not well-documented, but they are thought to be rare below 1,500 m (Harrisson 1955a, Smythies 1999). The species is known to eat insects, fruit (e.g., Rubus berries), and nectar, e.g., of Schima wallichii, red rhododendrons, and heather flowers (Harrisson 1955a, Steinheimer 1999, Ramji 2010).

The Mountain Black-eye comprises four recognized subspecies: C. e. emiliae on Kinabalu, C. e. trinitae on Trus Madi, C. e. fusciceps from the "Ulu Trusan," and C. e. moultoni on Mulu, Murud, Tama Abo, and Pueh (Harrisson 1955a, Mees 1955, Harrisson 1956). The subspecific status of populations on Tambuyukon, Alab, Nyiut, and Harun is unknown, as no specimens have been collected from those sites. Presumably, these populations group with the closest well-studied population (e.g., the Tambuyukon subspecies would be C. e. emiliae of nearby Kinabalu). Recent study of morphometric variation among C. e. emiliae, C. e. trinitae, and C. e. moultoni (Ramji et al. 2012b) has shown that they differ from one another in bill and tarsus length. C. e. emiliae is larger than the other three, perhaps reflecting the effect of Bergmann's Rule given Kinabalu's unusually high elevation (Mees 1955). Multivariate analysis of plumage has shown that $C$. $e$. emiliae and C. e. moultoni are distinct, with the former generally darker and the latter brighter yellow, and that $C$. e. trinitae is intermediate between them (Ramji 2010, Ramji and Rahman 2011).

Their sky-island distribution and subspecific differentiation make black-eyes an excellent group for studying processes of diversification on Borneo (Knowles 2000, 2001, McCormack et al. 2008). If Borneo's montane forest descended as low as 1,400 $\mathrm{m}$ during the LGM-as was apparently the case in Sumatra (Flenley 1998) - the currently disjunct black-eye populations had a recent opportunity to come together and interbreed. Thus, little genetic differentiation should be expected among them, especially between Sabah and northern Sarawak, where interpopulation distances are relatively short and largely mountainous regions intervene (Figure 1). The distant and isolated populations of Pueh and Nyiut $(>600 \mathrm{~km}$ from northern Sarawak), however, might not have mixed with other populations during the LGM and, thus, would remain distinct. Alternatively, as suggested by morphology, black-eye populations in Sarawak may not have interbred with those of Sabah during the LGM, but remained disjunct. Such a result would be consistent with the population structure of other montane passerine species that have distinct subspecies in Sabah. If Sabah and Sarawak populations of black-eyes are, in fact, genetically distinct, that would mean either that the montane forest did not descend low enough during the LGM to allow geographically isolated populations to intermingle and interbreed, or that the populations were already reproductively isolated during the LGM and, hence, have a divergence date much older than the LGM. Furthermore, the discovery that populations of birds in the mountains of Sabah versus Sarawak are genetically distinct would mean that they share the same population subdivision as many lowland forest bird species (Moyle et al. 2005, Sheldon et al. 2009, Lim et al. 2010, Lim et al. 2011). Such a result would require us to search for a geographic event or series of events that could cause vicariance simultaneously in montane and lowland bird populations.

To investigate the degree of population differentiation in Mountain Black-eyes and to determine if populations in Sabah and Sarawak are distinct from each other, we compared the major populations of this species using four mitochondrial DNA loci. Although reconstructions of diversification based on single markers such as mtDNA can be misleading (e.g., as shown by Carling and Brumfield 2008, Harris et al. 2013), we nevertheless chose the fastevolving mitochondrial loci for several reasons. First, the recent and dramatic radiations of white-eyes suggest that populations of black-eyes would be closely related to one another (Warren et al. 2006, Moyle et al. 2009, Melo et al. 2011); second, nuclear gene sequences have, so far, proved largely ineffective in resolving relationships among closely related taxa (e.g., in Southeast Asia: Moyle et al. 2009, Lim and Sheldon 2011, Sheldon et al. 2012); finally, the resolving power of mitochondrial DNA at the population level is well-established (Barrowclough and Zink 2009).

\section{METHODS}

Thirty-eight vouchered individual black-eyes from five populations in Malaysia were sampled for molecular comparison (Figure 1): nine from Kinabalu $\left(06^{\circ} 03^{\prime}\right.$ $\left.30^{\prime \prime} \mathrm{N}, 116^{\circ} 34^{\prime} \mathrm{E}\right)$, seven from Trus Madi $\left(05^{\circ} 33^{\prime} \mathrm{N}, 116^{\circ}\right.$ $\left.30^{\prime} \mathrm{E}\right), 10$ from Mulu $\left(04^{\circ} 03^{\prime} \mathrm{N}, 114^{\circ} 55^{\prime} \mathrm{E}\right)$, seven from Murud $\left(03^{\circ} 55^{\prime} \mathrm{N}, 115^{\circ} 30^{\prime} \mathrm{E}\right)$, and five from Pueh $\left(01^{\circ}\right.$ $\left.43^{\prime} \mathrm{N}, 109^{\circ} 40^{\prime} \mathrm{E}\right)$. Specimens and tissues are stored at the Zoology Department, Universiti Malaysia Sarawak, Malaysia, and the Museum of Natural Science, Louisiana State University, USA.

Genomic DNA was extracted from blood and muscle tissues using DNeasy blood and tissue kits (Qiagene, Valencia, California, USA). Six pairs of primers (Table 1) were used to amplify complete sequences of Cytochrome $b$ (Cytb) and the second and third subunits of NADH genes (ND2 and ND3), as well as part of the control region (CR) 
TABLE 1. Primers used in this study.

\begin{tabular}{|c|c|c|c|c|}
\hline Gene & Primer & Sequences & References & Annealing temperature \\
\hline \multirow[t]{2}{*}{ ND2 } & L5215 & TATCGGGCCCATACCCCGAAAAT & Hackett 1996 & $49^{\circ} \mathrm{C}$ \\
\hline & $\mathrm{H} 6313$ & CTCTTATTTAAGGCTTTGAAGGC & Johnson and Sorenson 1998 & \\
\hline \multirow[t]{2}{*}{ ND3 } & L10755 & GACTTCCAATCTTTAAAATCTGG & Chesser 1999 & $50^{\circ} \mathrm{C}$ \\
\hline & $\mathrm{H} 11151$ & GATTTGTTGAGCCGAAATCAAC & Chesser 1999 & \\
\hline \multirow[t]{2}{*}{ Cytb1 } & L15656 & AACCTACTAGGAGACCCAGA & Helm-Bychowski and Cracraft 1993 & $55^{\circ} \mathrm{C}$ \\
\hline & H16065 & GGAGTCTTCAGTCTCTGGTTTACAAGAC & Helm-Bychowski and Cracraft 1993 & \\
\hline \multirow[t]{2}{*}{ Cytb2 } & L14857 & AGGATCATTCGCCCTATCCAT & Barker et al. 2008 & $47.5^{\circ} \mathrm{C}$ \\
\hline & H15298 & GCCCCTCAGAATGATATTTGTCCTCA & Helm-Bychowski and Cracraft 1993 & \\
\hline \multirow[t]{2}{*}{ Cytb3 } & L15191 & ATCTGCATCTACCTACACATCGG & Lanyon and Hall 1994 & $52^{\circ} \mathrm{C}$ \\
\hline & H15709 & GGCATATGCGAATARGAARTATCA & Lee et al. 1996 & \\
\hline \multirow[t]{2}{*}{ Control region } & L816 & GATGCACTTTGACCCCATTC & Gawin 2007 & $53^{\circ} \mathrm{C}$ \\
\hline & $\mathrm{H} 1251$ & TCTTGGCATCAGCTTCAGTGCCRTGC & Sorenson et al. 1999 & \\
\hline
\end{tabular}

consisting of a section of the conserved domain and the complete third domain (Baker and Marshall 1997). PCR was run using the following thermal-cycling profile: initial denaturation at $95^{\circ} \mathrm{C}$ for $10 \mathrm{~min}$, followed by 40 cycles of denaturation at $95^{\circ} \mathrm{C}$ for $30 \mathrm{~s}$, annealing at a locus-specific temperature for each primer for $45 \mathrm{~s}$ (Table 1), extension at $72^{\circ} \mathrm{C}$ for $2 \mathrm{~min}$, and a final extension at $72^{\circ} \mathrm{C}$ for $10 \mathrm{~min}$. Sequencing was performed using a BigDye Terminator kit v3.1 and an ABI PRISM 3730xl Beckman Coulter Genomics sequencer (Danver, Massachusetts, USA). Sequences were edited and aligned using Sequencher ver. 4.7. The sequences are deposited at Genbank: 848323-848474.

Sequence variability and genetic distances were determined using MEGA 5.2.1 (Tamura et al. 2011). Haplotype summary data for each sequence-type and concatenated data were generated using DnaSP ver. 5 (Librado and Rozas 2009). To test for agreement with a model of neutral evolution, we calculated Tajima's $D$ statistic (Tajima 1989) and also performed the McDonald-Kreitman test on coding genes (McDonald and Kreitman 1991) in DnaSP. Tajima's $D$ was tested against the null assumption of a beta distribution, and the McDonald-Kreitman test was assessed with Fisher's exact test. We also investigated population structure under the framework of nested analysis of molecular variance (AMOVA), computing the fraction of total genetic variation distributed within and among clades and populations using Tamura-Nei distances (Tamura and Nei 1993). The significance of this partitioning against a null model of no significant difference was tested with a permutation procedure (Excoffier et al. 1992). AMOVA and Minimum Spanning Networks (MST) were calculated with ARLEQUIN ver. 3.5.1.2 (Excoffier et al. 2005). Following initial analyses that suggested that Sabah populations (Kinabalu and Trus Madi) and Sarawak populations (Mulu, Murud, and Pueh) are distinct genetic entities, we conducted two sets of AMOVA: with Sabah and Sarawak populations together and separated. To examine the relationship between genetic and geographic distances, Mantel Tests were conducted in ARLEQUIN.
MSTs were viewed and edited using HapStar ver. 0.7 (Teacher and Griffiths 2011).

We estimated gene trees from the individual mtDNA loci (ND2, ND3, Cytb, and CR) and concatenated sequences via Bayesian phylogenetic inference in BEAST ver. 1.6.2 (Drummond and Rambaut 2007), which simultaneously estimates the topology and branch lengths in units of millions of years. Japanese White-eye (Zosterops japonicus) served as outgroup (Genbank numbers: ND2 GU724482.1, ND3 FJ460869.1, Cytb AB159166.1, CR AB248943.1). We used jModeltest ver. 2.1.3 and AIC model-selection to determine that $\mathrm{HKY}+\mathrm{G}$ is the best substitution model for the four mtDNA loci and the concatenated sequences. To determine the rate of molecular evolution required for black-eye population divergence at the LGM, we reconstructed gene trees using the LGM as a calibration point (the "biogeographic calibration"). To compare this rate with the standard passerine bird mtDNA rate, we also constructed gene trees using the Cytb value of $2 \%$ per million years (Weir and Schluter 2008). This we call the "molecular clock" rate. For the biogeographic calibration, we specified the distribution of time-to-most-common-recent-ancestor (TMRCA) of all ingroup taxa as after the LGM, using a uniform distribution ranging from 17,500 to 18,500 years ago, and we estimated the substitution rate using a relaxed uncorrelated lognormal clock with an uninformative prior (uniform distribution $=0.5-0.001$ ). For the molecular clock approach, we used $2 \%$ sequence divergence per million years and specified a relaxed uncorrelated lognormal distribution with a mean of 0.01 and stdev of 0.1 for the ucld.mean prior distribution. For all analyses, we used a coalescent constant size for the tree prior. The Markov chain Monte Carlo process was fixed to a length of $50,000,000$ with sampling every 5,000 generations. These lengths ensured a suitable effective sample size (ESS) of $>200$ for all parameters. Specifically, the parameter settings for the biogeographic calibration were: parameter id = "constant.popSize"; coalescentTree id = "starting- 
TABLE 2. Averaged uncorrected percent control region distances (lower left) and Cytb distances (upper right) among the five black-eye populations. Values were computed as complete deletion/pairwise deletion.

\begin{tabular}{lccccc}
\hline Population & Kinabalu & Trus Madi & Murud & Mulu & Pueh \\
\hline Kinabalu & & $0.2 / 0.3$ & $2.1 / 2.2$ & $2.1 / 2.1$ & $1.7 / 1.8$ \\
Trus Madi & $0.1 / 0.1$ & & $2.0 / 2.2$ & $2.0 / 2.1$ & $1.6 / 1.8$ \\
Murud & $2.3 / 2.6$ & $2.1 / 2.2$ & & $0.4 / 0.5$ & $0.4 / 0.4$ \\
Mulu & $2.3 / 2.6$ & $2.1 / 2.5$ & 0 & & $0.3 / 0.3$ \\
Pueh & $3.1 / 3.5$ & $3.0 / 3.4$ & $0.9 / 0.9$ & $0.9 / 0.9$ & \\
\hline
\end{tabular}

Tree"; tmrca uniformPrior lower $=$ "0.0175" upper $=$ "0.0185"; kappa lognormalPrior mean $=5, \mathrm{sd}=1.25$, initial starting value $=2$; frequencies lognormalPrior mean $=$ 0.25 , sd $=1.0$, initial starting value $=0.25$; alpha lognormalPrior mean $=2$, sd $=1.0$, initial starting value $=2$; ucld.mean uniformPrior lower $=0.05$, upper $=0.5$, initial starting value $=0.5$; ucld.stedv uniformPrior upper $=$ infinity, lower $=0.0$ initial starting value $=0.33333$; treemodel.rootheight; and mcmc id = "mcmc" chainLength $=$ "50000000". Settings for the standard molecular clock were the same as for the biogeographic calibration, except: tmrca $=$ using tree prior; ucld.stedv lognormalPrior mean $=1.0$, sd $=1.0$, initial starting value $=0.33333$; ucld.mean lognormalPrior mean $=0.0125$, sd $=0.1$, and initial starting value $=1.0$. Each analysis was run twice. We used Tracer v. 1.5 (Drummond and Rambaut 2007) to check the ESS of each parameter and to determine the $10 \%$ burn-in cutoff, and we ran each analysis multiple times to ensure our results were stable. We used Tree Annotator v. 1.6.2 to generate a Maximum Clade Credibility tree with mean nodal ages and 95\% Highest Posterior Density (HPD) ranges.

\section{RESULTS}

In all, 2,194 bases of 38 black-eye individuals from five populations were sequenced: 1,143 of Cytb, 491 of ND2, 318 of ND3, and 242 of CR. Variable and parsimony informative sites for each sequence type, respectively, were: Cytb, 41 and 31; ND2, 18 and 16; ND3, 13 and 12; and CR, 12 and 9 . When nucleotide sequences were translated into amino acids, variable and parsimony informative sites were, respectively: Cytb, 5 and 2; ND2, 6 and 6; and ND3, 5 and 4. The three protein coding sequences displayed substitution patterns consistent with coding mtDNA rather than nuclear pseudogenes (i.e. no indels, no stop codons, and rates of substitution for codon positions such that $2<1<3$ ). Tajima's $D$ for all sequence types did not differ significantly from a model of neutral evolution, nor did the McDonald-Kreitman test. Uncorrected pairwise proportional distances among populations were similar for each gene and the control region, i.e. about $2 \%$ between Sabah and Sarawak populations, and $<1 \%$ for populations within Sabah and within Sarawak (Cytb and CR distances shown in Table 2).

Nine haplotypes were identified for ND2, eight for ND3, 22 for Cytb, 10 for CR, and 26 for the concatenated sequences (Table 3). Mt. Kinabalu had the most haplotypes and Pueh the fewest. Relatively few haplotypes were shared among populations: Kinabalu and Trus Madi shared four, while Mulu and Murud shared one (Figure 3). No Cytb or concatenated haplotypes were shared (Figures 3 and 4). Minimum spanning trees of the four loci and the concatenated sequences (Figures 3 and 4) all displayed a similar pattern, with the Sabah populations (Kinabalu and Trus Madi) forming a group distinctly separate from the Sarawak populations (Mulu, Murud, and Pueh). The differences between the Sabah and Sarawak groups were: 6 nucleotides of ND2, 2 of ND3, 18 of Cytb, 7 of CR, and 41 of the concatenated data. Haplotype differences within each Sarawak population for each of the four loci were 1-3 nucleotides and 4-13 nucleotides in the concatenated genes. The Pueh population was separated from other Sarawak populations by 2 nucleotides in ND2, 3 in ND3, 1 in Cytb, 2 in CR, and 13 in the concatenated data. Between Kinabalu and Trus Madi in Sabah, the hyplotype differences were 1 nucleotide each in ND2 and Cytb, 12 nucleotides in ND3, and up to 5 nucleotides in the concatenated genes.

AMOVA conducted under the assumption that the five populations represent a single group revealed significant levels of genetic differentiation among all populations $\left(\mathrm{ND} 2 \mathrm{~F}_{\mathrm{st}}=0.93194\right.$, ND3 $\mathrm{F}_{\mathrm{st}}=0.82537$, Cytb $\mathrm{F}_{\mathrm{st}}=0.92069$, CR $F_{\text {st }}=0.89095$, Concatenated $\left.F_{\text {st }}=0.90710\right)$. When the populations were subdivided into Sarawak and Sabah groups, the two groups were significantly different from

TABLE 3. Number of haplotypes for each population.

\begin{tabular}{lrcccccccccc}
\hline Population & $n$ & $\mathrm{H}_{\mathrm{ND} 2}$ & $\mathrm{H}_{\mathrm{ND} 3}$ & $\mathrm{H}_{\mathrm{CYTB}}$ & $\mathrm{H}_{\mathrm{CR}}$ & $\mathrm{H}_{\mathrm{CON}}$ & $\mathrm{Hp}_{\mathrm{ND2}}$ & $\mathrm{Hp}_{\mathrm{ND} 3}$ & $\mathrm{Hp}_{\mathrm{CYTB}}$ & $\mathrm{Hp}_{\mathrm{CR}}$ & $\mathrm{H}_{\mathrm{CON}}$ \\
\hline Kinabalu & 9 & 4 & 4 & 7 & 5 & 8 & 3 & 3 & 7 & 3 & 8 \\
Trus Madi & 7 & 2 & 2 & 3 & 2 & 5 & 1 & 1 & 3 & - & 5 \\
Murud & 7 & 2 & 2 & 7 & 2 & 4 & 2 & 1 & 7 & 2 & 4 \\
Mulu & 10 & 1 & 1 & 4 & 2 & 7 & 1 & - & 4 & 2 \\
Pueh & 5 & 1 & 1 & 1 & 1 & 1 & 1 & 1 & 1 & 1 & 1
\end{tabular}

$n=$ number of individuals, $\mathrm{H}=$ number of haplotypes for each gene, $\mathrm{Hp}=$ number of private haplotypes for each gene 


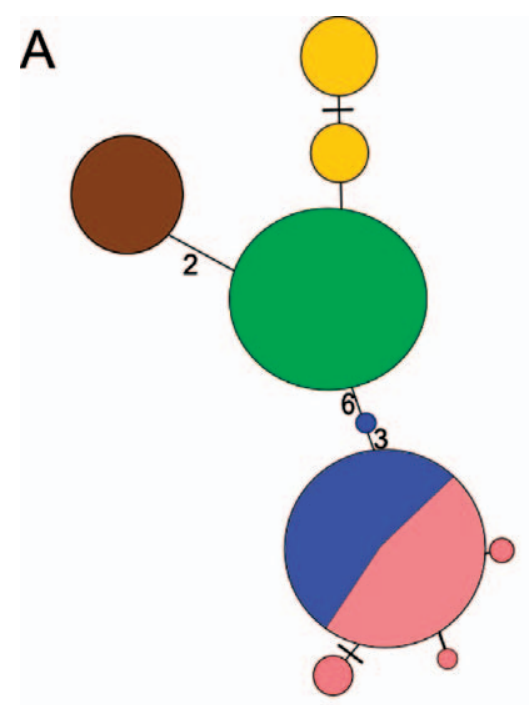

B
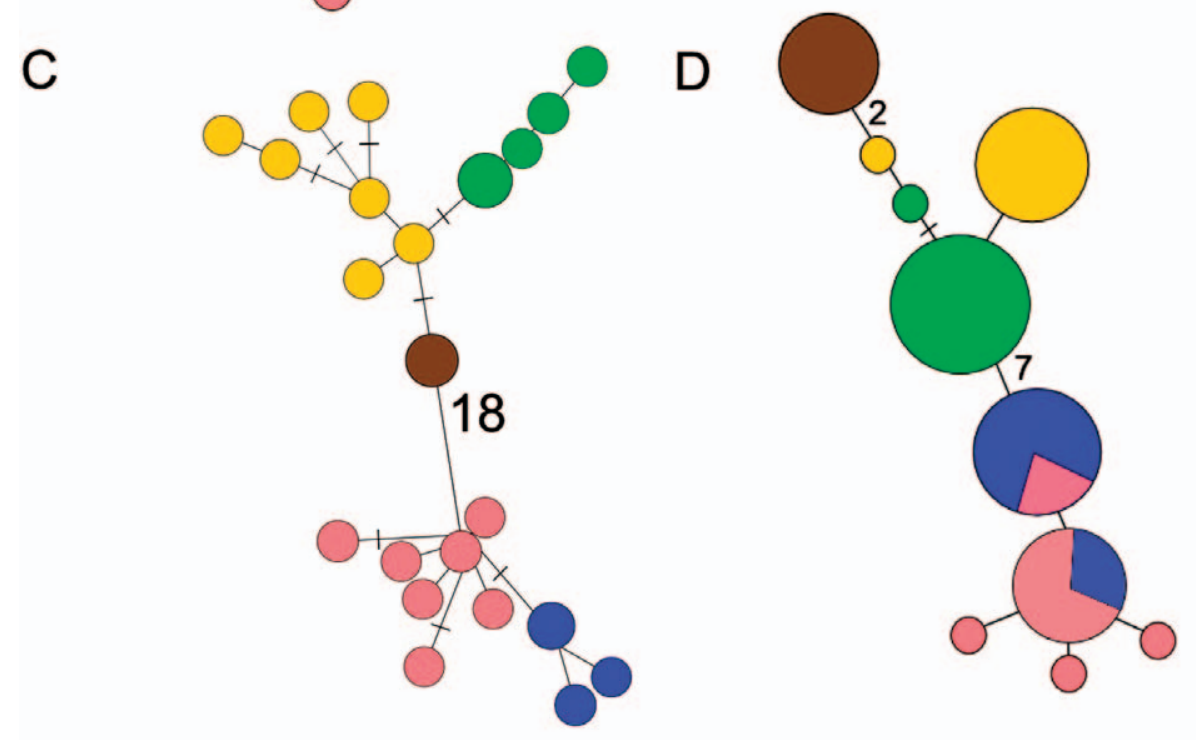

\section{Populations:}

Kinabalu Trus Madi

Mulu

Murud Pueh

FIGURE 3. Minimum spanning trees of (A) ND2, (B) ND3, (C) Cytb, and (D) CR. Circle sizes are proportional to haplotype frequencies. Each circle represents a haplotype or shared haplotypes (Table 3). Different colors indicate haplotypes from the five sampled populations. Branches with hatch marks represent a single nucleotide substitution. Numbers next to branches indicate number of substitutions.

one another $\left(\mathrm{ND} 2 \mathrm{~F}_{\mathrm{ct}}=0.80467, \mathrm{ND} 3 \mathrm{~F}_{\mathrm{ct}}=0.50939\right.$, Cytb $\mathrm{F}_{\mathrm{ct}}=0.83288, \mathrm{CR} \mathrm{F}_{\mathrm{ct}}=0.68187$; Concatenated $\mathrm{F}_{\mathrm{ct}}=$ 0.77577), as were most populations within these two groups $\left(\mathrm{ND} 2 \mathrm{~F}_{\mathrm{sc}}=0.75881, \mathrm{ND} 3 \mathrm{~F}_{\mathrm{sc}}=0.71323\right.$, Cytb $\mathrm{F}_{\mathrm{sc}}=$ $0.67713, \mathrm{CR} \mathrm{F}_{\mathrm{sc}}=0.74660$, Concatenated $\mathrm{F}_{\mathrm{sc}}=0.70861$ ). Within Sabah, however, the difference between Kinabalu and Trus Madi was significant at only one locus (Cytb) and not for the concatenated data (Table 4). A Mantel test revealed a significant correlation between pairwise $F_{s t}$ values (Table 4) and geographic distance between populations (Concatenated $r=0.36 ; p=0.04$ ). In light of the haplotype structure (Figures 3 and 4), these results suggest that Sarawak and Sabah populations first separated from one another and then the Sarawak populations differentiated among themselves.

Phylogenetic reconstruction using BEAST indicated black-eye populations are monophyletic relative to the outgroup Zosterops japonicus regardless of whether genes were examined individually or as a group (Figure 5). The populations from Sabah formed a clade separate from Sarawak populations. In Sabah, Trus Madi nested within Kinabalu, whereas all Sarawak populations were mono- 


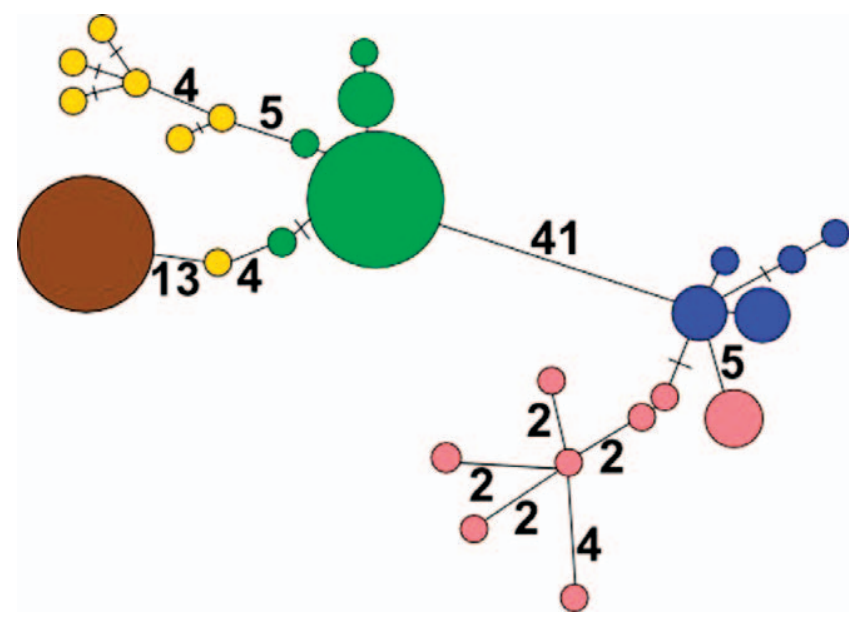

FIGURE 4. Minimum spanning trees of concatenated genes. Description of circles and branches in Figure 3.

phyletic. Overall the BEAST trees were consistent with the haplotype network patterns (Figures 3 and 4). When divergence among populations was constrained in BEAST to occur since the LGM (biogeographic calibration), the mean rate of molecular evolution of each DNA sequence type was extremely fast (Figure 6): CR 0.424 substitutions/ site/million years (s/s/MY), Cytb 0.472 s/s/MY, ND2 0.502 $\mathrm{s} / \mathrm{s} / \mathrm{MY}$, ND3 $0.43 \mathrm{~s} / \mathrm{s} / \mathrm{MY}$, and concatenated sequences $0.486 \mathrm{~s} / \mathrm{s} / \mathrm{MY}$. When the rate was set to $2 \%$ between sequences/MY (avian molecular clock), they were much slower: CR, 0.0128 s/s/MY, Cytb 0.0132 s/s/MY, ND2 $0.0137 \mathrm{~s} / \mathrm{s} / \mathrm{MY}, \mathrm{ND} 30.0133 \mathrm{~s} / \mathrm{s} / \mathrm{MY}$; and concatenated $0.0130 \mathrm{~s} / \mathrm{s} / \mathrm{MY}$. Even though white-eye $\mathrm{mtDNA}$ rates are known to be higher than 2\% per MY, e.g., 4.66\% per MY for four concatenated genes (Warren et al. 2006) and 3.5\% for ND2 (Moyle et al. 2009, personal observation), the unreasonably high value of the biogeographic rate (Figure 6 ) indicates that black-eye populations diverged from one another long before the LGM (Figure 5).

\section{DISCUSSION}

\section{The Effect of Ecology on Black-eye Distribution}

Phylogenetic reconstruction (Figure 5) and haplotype comparisons (Figures 3 and 4) indicate that Mountain Black-eyes fall into two reciprocally monophyletic and well-differentiated clades: one in Sabah, comprising populations on Kinabalu and Trus Madi, and the other in Sarawak, comprising populations on Mulu, Murud, and Pueh. Based on comparisons of the rate of sequence evolution (Figures 5 and 6), these two clades diverged long before the last glacial maximum, probably in the midPleistocene. Thus, black-eye evolution was influenced by numerous glacial cycles (Augustin et al. 2004), precluding at this stage the identification of key events in the species'
TABLE 4. Pairwise $F_{s t}$ and geographic distance between populations. Lower left corner has $F_{s t}$ values for ND2, ND3, Cytb, CR, and Concatenated sequences, respectively. Underlined values indicate non-significant $F_{s t}$ values. Upper right has distances in kilometers.

\begin{tabular}{lcclll}
\hline & Kinabalu & Trus Madi & Murud & Mulu & Pueh \\
\hline Kinabalu & - & 60 & 265 & 285 & 900 \\
Trus Madi & $\underline{0.04605}$ & - & 215 & 240 & 860 \\
& $\underline{\underline{0.10370}}$ & & & & \\
& 0.53836 & & & & \\
& $\underline{0.17954}$ & & & & \\
Murud & $\underline{0.19414}$ & & & 65 & 690 \\
& 0.90807 & 0.94505 & - & & \\
& 0.72517 & 0.81481 & & & \\
& 0.90845 & 0.93047 & & & \\
Mulu & 0.84516 & 0.88569 & & & \\
& 0.88192 & 0.97656 & & & \\
& 0.94649 & 0.98945 & 0.77751 & - & \\
& 0.82548 & 0.94137 & $\underline{0.23497}$ & & \\
& 0.94810 & 0.97041 & 0.66231 & & \\
Pueh & 0.90289 & 0.93357 & 0.49161 & & \\
& 0.93029 & 0.96681 & 0.63617 & & \\
& 0.93166 & 0.98557 & 0.86867 & 1.0 & \\
& 0.84418 & 0.94628 & 0.87676 & 1.0 & \\
& 0.93633 & 0.97653 & 0.63106 & 0.89726 & \\
& 0.94249 & 0.97476 & 0.87863 & 0.94412 & \\
& 0.92558 & 0.97446 & 0.82449 & 0.95510 & \\
& & & & &
\end{tabular}

diversification history. The populations of Sabah and Sarawak may well have come into contact during the LGM, but were too genetically or behaviorally isolated by that late date for gene flow to occur. Alternatively, they may have remained isolated from each other. Numerous ecological factors would have influenced the chances of population overlap and interbreeding during glacial periods. Implicit in linking the lower limit of montane forest to the situation at the LGM is the assumption that all meteorological parameters (e.g., temperature, humidity, cloud cover, rainfall amounts and seasonality, and wind strengths and directions) varied predictably in all parts of the physiographically variable mountains of Borneo and brought all upper montane populations into contact. This assumption is not realistic. Moreover, the apparent requirement of alpine meadow for black-eye nesting further reduces the chance of population mixing, even if birds encountered one another while foraging in upper montane forest. Bornean alpine meadow occurs above the tree line on Kinabalu starting at about 3,000 m, but at substantially lower elevations on all the other peaks due to the Massenerhebung effect (Grubb and Whitmore 1966, Grubb 1971). It requires specific soil conditions, moisture, wind, and light exposure, which explains its current patchy distribution on lower elevation peaks. During glacial cycles, patches of alpine meadow might have occurred more often and at lower elevation than at present due to general lowering of upper montane forest, but they would 


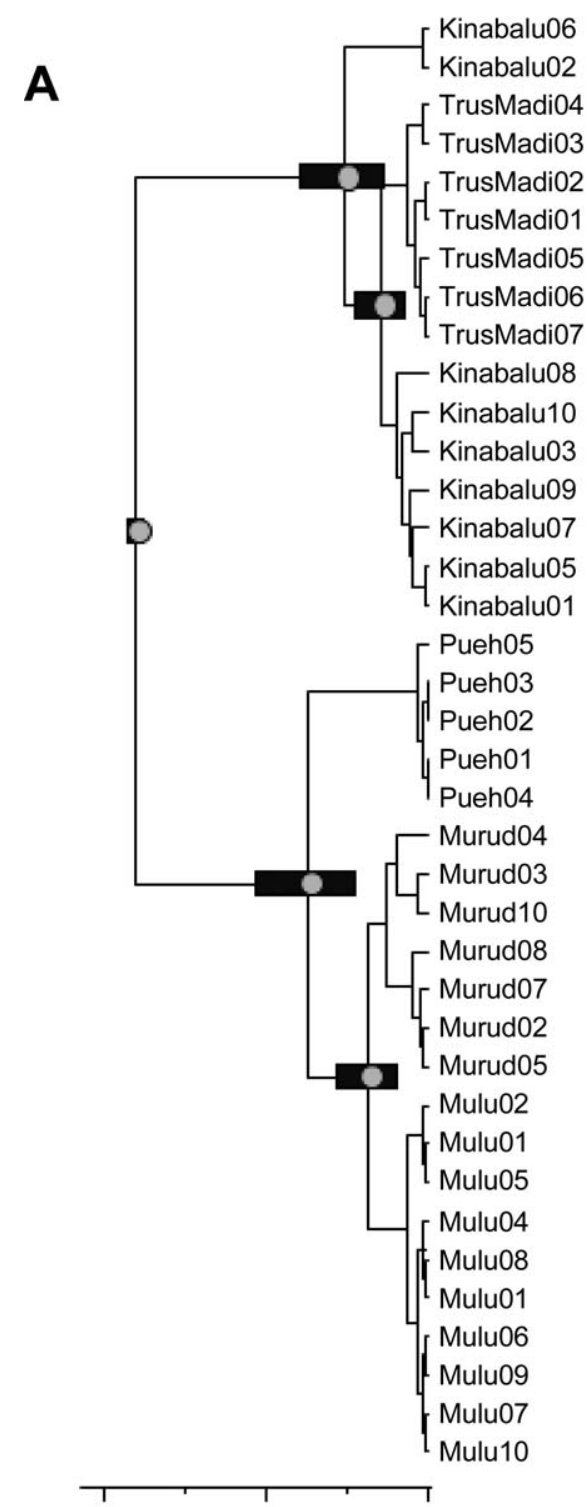

$\begin{array}{lll}0.02 & 0.01 \quad 0.0\end{array}$

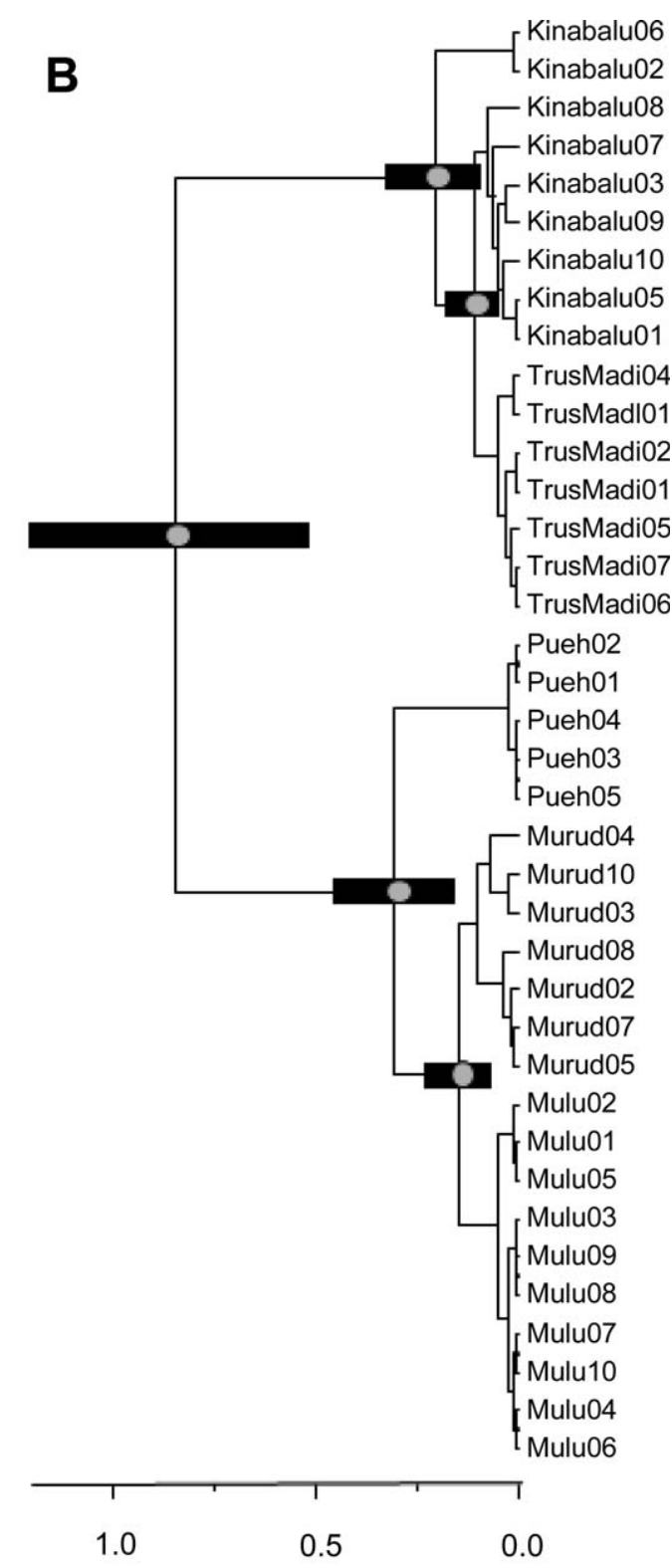

Time (million years ago)

FIGURE 5. BEAST trees from concatenated genes representing (A) biogeographic and (B) molecular clock rate determination. Node age ( $95 \%$ highest posterior density distribution) is indicated with heavy black bars. Nodal support of $100 \%$ is indicated with a gray dot. Zosterops japonicus served as outgroup.

still be restricted to individual peaks and ridges, thus potentially maintaining the subdivision of breeding populations.

\section{Phylogeography within Sabah and Sarawak}

Within each Malaysian state, a pair of populations share haplotypes-Kinabalu and Trus Madi in Sabah, and Mulu and Murud in Sarawak-presumably because of their close proximity and extensive intervening hills $(>900 \mathrm{~m})$ between the disjunct populations. The Pueh population clearly falls within the Sarawak group, but is distinct from the Mulu and Murud populations. Of the populations not compared in this study, we can assume that Tambuyukon and Alab lie within the Sabah group because both occur close to Kinabalu and Trus Madi (maximum distance, Alab to Trus Madi, is $35 \mathrm{~km}$ ) and the entire area surrounding these populations is mountainous. Similarly, we can assume that Tama Abo birds are closely allied to those of adjacent Murud, and that Nyiut, which is geographically close to Pueh, is part of the Sarawak group. The 


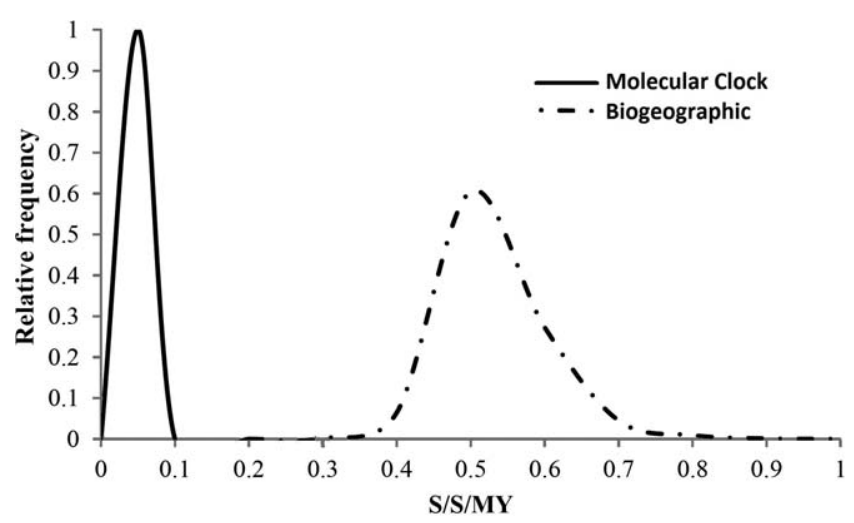

FIGURE 6. Posterior molecular rate probability distributions of the biogeographic calibration based on the Last Glacial Maximum (dotted line) versus the commonly accepted $2 \%$ per MY molecular clock (solid line). S/S/MY = substitutions per site per million years.

phylogeographic positions of the populations between Sabah and Sarawak, namely, C. e. fusciceps and Mt. Harun, are more difficult to place by proxy. These populations lie in the same mountainous region as Murud and are separated from the northern Sabah populations by $\sim 60$ $\mathrm{km}$ of generally lower-elevation terrain with few high ridges (see figure 7.9 in MacKinnon et al. 1996). But C. e. fusciceps (at least) may represent a morphologically distinct population (Banks 1952, Mees 1955) and, thus, have been separated long enough from other populations to achieve measurable genetic divergence.

A relatively close relationship between Pueh and northern Sarawak populations was previously indicated by their inclusion in C. e. moultoni (Mees 1955) and by quantitative examination of their morphometrics and plumage (Ramji 2010, Ramji and Rahman 2011, Ramji et al. 2012b). Nevertheless, the unique geographic characteristics and isolation of Mt. Pueh shed doubt on whether these morphological assessments reflect true relationship. T. Harrisson of the Sarawak Museum, for one, was extremely skeptical (Harrisson 1955a, Harrisson 1956). Pueh lies more than $600 \mathrm{~km}$ from Mulu and Murud, and it is not part of the central mountain chain of Borneo. It is also unusually low in elevation $(1,552 \mathrm{~m})$ compared with the other black-eye sites; all northern populations are associated with peaks $>1,800 \mathrm{~m}$ and lie in continuous mountains. Moreover, Pueh has a distinct and depauperate montane avifauna (Banks 1952), which includes its own subspecies of Bornean Whistler (Pachycephala hypoxantha sarawacensis), Snowy-browed Flycatcher (Ficedula hyperythra mjöbergi), and White-throated Fantail (Rhipdura albicollis sarawacensis). Taken together, these lines of evidence suggested that black-eyes on Mt. Pueh might constitute a genetically distinct population that does not belong in C. e. moultoni. Until recently, however, fresh material for molecular comparisons of Pueh's black-eyes was not available because the population was thought extinct. This changed in 2011 with its rediscovery (Ramji et al. 2012a), and new genetic samples have allowed us to confirm the unexpectedly close relationship between Pueh and northern Sarawak populations.

\section{Black-eye Phylogeography and Bornean Bird Diversification}

The division of black-eyes into Sabah and Sarawak groups raises interesting issues concerning the biogeographic history of Bornean birds as a whole. From work on lowland taxa (Lim et al. 2010, Lim et al. 2011, Lim and Sheldon 2011) and preliminary studies of montane populations (Moyle et al. 2005, Moyle et al. 2011), we have been developing scenarios of passerine evolution on Borneo. Many lowland species are divided morphologically and genetically in rough accordance with the Sabah border. Some well-known examples are the falconets (Microhierax fringillarius vs. M. latifrons), Yellow-bellied Bulbul (Alophoixus phaeocephalus diardi vs. A. p. connectens), Boldstriped Tit-Babbler (Macronus bornensis bornenis vs. $M . b$. montanus), Short-tailed Babbler (Malacocincla malaccensis poliogenis vs. M. m. sordida), shamas (Copsychus malabaricus suavis vs. C. m. stricklandii), and Oriental Magpie-Robin (C. saularis musicus vs. C. s. pluto/adamsi) (Sheldon et al. 2009, Lim et al. 2010, Lim et al. 2011, Irham et al. 2012). Substantial evidence indicates that lowland bird populations were subdivided, presumably during one or more glacial periods, into forest refugia in western Sundaland and eastern Borneo, as were other groups of Sundaic organisms (e.g., Brandon-Jones 1998, Thomas 2000, Gathorne-Hardy et al. 2002, Gorog et al. 2004, Bänfer et al. 2006, Iwanaga et al. 2012, Ohtani et al. 2013). This subdivision would have occurred as lowland forest retreated or shifted position and montane forest expanded and dominated central Borneo (Figure 2B). The refugia responsible for division of lowland birds in Borneo must have been in place long before the LGM, given substantial genetic divergence between eastern and western populations, i.e. $>2 \%$ for mitochondrial coding genes (Lim et al. 2010, Lim et al. 2011). These divergence values are more in accord with the division of dipterocarps into eastern and western groups in the mid-Pleistocene (Iwanaga et al. 2012, Ohtani et al. 2013). Subsequent to glacial periods, when lowland forest reoccupied central Borneo (Cannon et al. 2009), populations of birds from the eastern and western lowland refugia would have expanded along with lowland forest habitat and come into contact. Currently, the main zone of contact is near the Sabah border, but it may well be dynamic, moving either east or west, and north or south. Also, different contact zones may exist for taxa that inhabited refugia of different ages or distributions. 
In contrast to this scenario of isolation into lowland forest refugia during glacial periods and expansion and secondary contact during interglacials, we expected montane species to exhibit a different biogeographic pattern. Rather than being pushed into refugia during glacial periods, montane species should instead have experienced population expansion due to expansion of montane forest habitat to lower elevations (Figure 2B). This prediction, however, is contradicted by black-eye phylogeography. The black-eyes are divided, similarly to lowland species, into Sarawak and Sabah groups, and these groups are about $2 \%$ divergent from one another (Table 2). Moreover, this phylogeographic break is probably not unique to black-eyes among montane passerines. Several other species with distributions that span Borneo's spinal mountain range are divided morphologically between Sabah and the rest of Borneo: e.g., Ochraceous Bulbul (Alophoixus ochraceus ruficrissus vs. A. o. fowleri), Temminck's Babbler (Pellorneum pyrrogenys canicapillus vs. P. p. erythrote \& longstaffi), Grey-throated Babbler (Stachyris nigriceps borneensis vs. S. n. hartleyi), and Chestnut-hooded Laughingthrush (Garrulax treacheri treacheri vs. damnatus \& griswoldi). Moreover, phylogeographic studies of two montane tree taxa, Lithocarpus and Trigonobalanus (Kamiya et al. 2002, Cannon and Manos 2003), found a similar genetic division between Mt. Kinabalu and the Kelabit Highlands (adjacent to Murud and the Tama Abo Range in Sarawak).

Why Borneo's montane bird species are subdivided in a fashion similar to its lowland species is not known. To discover the reason will require substantial improvement in two distinct lines of research. First, paleo-climatic and vegetation modeling must address geologic events earlier than the LGM. Based on genetic divergence values in a wide variety of studies in addition to our own (e.g., Gorog et al. 2004, den Tex et al. 2010, Ohtani et al. 2013), the timescale of Borneo's avifaunal division is two orders of magnitude older than the LGM, perhaps nearer one million years than 10,000 years. Thus, models explaining the state of geography at the LGM, although extremely helpful in indicating what may happen to habitats during glacial cycles, may not apply to the mid or early Pleistocene. Moreover, further paleontological study is required to improve baseline data used in paleo-habitat reconstruction. Morley (2000:210) stressed the difficulty in determining lapse rate (rate of forest movement with temperature change) in lower versus higher mountains, noting a variety of factors that may confound the estimation, including edaphic effects and changes in ultraviolet radiation. In recognition of the uncertainty, Cannon et al. (2009) offered four scenarios of forest distribution in the LGM depending on the interaction of model parameters (Figure 2 shows the extremes). Thus, more paleontological information on the paleo-distribu- tions of forests, e.g., from palynological data, would help tremendously in formulating models. Second, more genetic studies are needed. From just a few sets of comparisons among lowland and montane birds, we have confirmed two distinct genetic patterns: division between Sabah and Sarawak populations in both the lowlands and the mountains, and replacement of lowland species at higher elevation by cryptic montane congeners, e.g., in Collocalia swiftlets, forktails, and gray spiderhunters (Moyle et al. 2005, Moyle et al. 2008, Moyle et al. 2011). Undoubtedly, more phylogeographic studies will uncover more such patterns.

\section{Genetic Diversity}

The genetic variation of each population examined in this study was potentially influenced by the area of the mountain on which each population resides and by our sampling methods. Kinabalu is by far the largest mountain, both in terms of its overall area and elevation. It is 1.5 times as high as any other mountain in Borneo and has much greater potential for haplotype diversity among its black-eyes than the other mountains. On all mountains, even Kinabalu, the areas sampled were small because of the logistic difficulty of collecting, and this limitation further reduced potential genetic diversity. Thus, the genetic variation reported in this paper must be considered to be a minimum estimate for each population, especially for Kinabalu.

\section{Taxonomy}

This study and recent morphological examinations of geographic variation in black-eyes (Gawin 2007, Ramji 2010, Ramji and Rahman 2011, Ramji et al. 2012b) support the current designation of subspecies (Mees 1955, Harrisson 1956). Birds from Kinabalu (C. e. emiliae) are larger and somewhat darker than those from Trus Madi ( $C$. e. trinitae), and both populations differ from C. e. moultoni of Mulu and Murud in size and darker coloration. The two specimens of C. e. fusciceps were not included in the recent morphological analyses, thus we cannot comment on the appropriateness of that subspecies. Morphology of the Pueh population also was not recently examined. However, given its genetic relatedness to Mulu and Murud populations, the Pueh population appears properly classified in C. e. moultoni.

\section{Conservation}

Most black-eye populations are well-protected by their inclusion in parks (Kinabalu, Tambuyukon, Alab, Mulu, Murud, Tama Abo, and Harun). The forest of Trus Madi above $900 \mathrm{~m}$ has Class 1 Protection, and it is further protected by Sabah's recognition of its importance to ecotourism (http://www.forest.sabah.gov.my/fmu10). Most populations are also inherently protected by their elevation 
and remoteness (including Murud, Tama Abo, Paya Maga, and Harun). Populations on Nyiut and Pueh, however, are not protected by remoteness, elevation, or special conservation interest. Pueh has been logged recently and is jeopardized especially by its location in a developed part of Sarawak. Black-eyes on these two peaks in particular merit further study to determine the extent of their prime habitat, population sizes, and genetic diversity.

\section{ACKNOWLEDGMENTS}

For permission to undertake research in Malaysia we thank the Prime Minister's Department, the Chief Ministers' Departments of Sabah and Sarawak, Sabah Parks, Wildlife, and Forestry departments, and Sarawak Forestry Department, Forestry Corporation, and Biodiversity Institute. We also thank the staff of Sabah Parks (Dr. Jamili Nais, Dr. Maklarin Lakim, Alim Biun, Paul Yambun, and Benedict Butit), Sabah Museum (Jaffit Majuakim, Albert Lo, Freddie Julus, Patrick Francis, and Mathius Angkaus), and UNIMAS (Pui Yong Min, Isa Said, Mohd Ridwan Abd Rahman, Mohamad Jalani Mortada, and Raymond Atet), and the following individuals: Kevin of Tebakang Bidayuh, Duwin and Sutar of Siru Dayak, Imelda Paul, and Peter Hosner, for extensive help in the field. We thank Chuck Cannon for permission to reproduce figure 1 from Cannon et al. (2009). Clare Brown and two anonymous reviewers helped improve the manuscript substantially with insightful editorial suggestions and comments on the roles of ecology and glacial cycles. This work was supported financially by NSF DEB-0228688 and DEB- 1241059 to FHS, FRGS/06(03)/647/2007(12) to MAR, and by the Coypu Foundation, Louisiana State University, and Universiti Malaysia Sarawak.

\section{LITERATURE CITED}

Alström, P., S. Hohna, M. Gelang, P. G. P. Ericson, and U. Olsson (2011). Non-monophyly and intricate morphological evolution within the avian family Cettiidae revealed by multilocus analysis of a taxonomically densely sampled dataset. BMC Evolutionary Biology 11:352.

Augustin, L., C. Barbante, P. R. F. Barnes, J. M. Barnola, M. Bigler, E. Castellano, O. Cattani, J. Chappellaz, D. Dahl-Jensen, B. Delmonte, G. Dreyfus, et al. (2004). Eight glacial cycles from an Antarctic ice core. Nature 429:623-628.

Baker, A., and H. D. Marshall (1997). Mitochondrial control region sequences as tools for understanding evolution. In Avian Molecular Evolution and Systematics (D. P. Mindell, Editor). Academic Press, San Diego, CA, USA. pp. 51-82.

Bänfer, G., U. Moog, B. Fiala, M. Mohamed, K. Weising, and F. R. Blattner (2006). A chloroplast genealogy of myrmecophytic Macaranga species (Euphorbiaceae) in Southeast Asia reveals hybridization, vicariance and long-distance dispersals. Molecular Ecology 15:4409-4424.

Banks, E. (1937). Birds from the highlands of Sarawak. Sarawak Museum Journal 4.

Banks, E. (1952). Mammals and birds from the Maga mountains in Borneo. Bulletin of the Raffles Museum 24:160-163.
Barker, F., A. Vandergon, and S. Lanyon (2008). Species status of the Red-Shouldered Blackbird (Agelaius assimilis): Implications for ecological, morphological, and behavioral evolution in Agelaius. The Auk 125:87-94.

Barrowclough, G. F., and R. M. Zink (2009). Funds enough, and time: mtDNA, nuDNA and the discovery of divergence. Molecular Ecology 18:2934-2936.

Bird, M. I., D. Taylor, and C. Hunt (2005). Palaeoenvironments of insular Southeast Asia during the last glacial period: A savanna corridor in Sundaland? Quaternary Science Reviews 24:2228-2242.

Brandon-Jones, D. (1998). Pre-glacial Bornean primate impoverishment and Wallace's line. In Biogeography and Geological Evolution of SE Asia (R. Hall and J. D. Holloway, Editors). Backhuys Publishers, Leiden, The Netherlands. pp. 393-403.

Cannon, C. H., and P. S. Manos (2003). Phylogeography of the Southeast Asian stone oaks (Lithocarpus). Journal of Biogeography 30:211-226.

Cannon, C. H., R. J. Morley, and A. B. G. Bush (2009). The current refugial rainforests of Sundaland are unrepresentative of their biogeographic past and highly vulnerable to disturbance. Proceedings of the National Academy of Sciences of the United States of America 106:11188-11193.

Carling, M. D., and R. T. Brumfield (2008). Integrating phylogenetic and population genetic analyses of multiple loci to test species divergence hypotheses in Passerina buntings. Genetics 178:363-377.

Chesser, R. (1999). Molecular systematics of the rhinocryptid genus Pteroptochos. The Condor 101:439-446.

Davison, G. W. H. (1992). Birds of Mount Kinabalu, Borneo. Natural History Publications (Borneo), Kota Kinabalu, Sabah, Malaysia.

den Tex, R. J., and J. A. Leonard (2013). A molecular phylogeny of Asian barbets: Speciation and extinction in the tropics. Molecular Phylogenetics and Evolution 68:1-13.

den Tex, R. J., R. Thorington, J. E. Maldonado, and J. A. Leonard (2010). Speciation dynamics in the SE Asian tropics: Putting a time perspective on the phylogeny and biogeography of Sundaland tree squirrels, Sundasciurus. Molecular Phylogenetics and Evolution 55:711-720.

Drummond, A. J., and A. Rambaut (2007). BEAST: Bayesian evolutionary analysis by sampling trees. BMC Evolutionary Biology 7:214.

Excoffier, L., P. Smouse, and J. Quattro (1992). Analysis of molecular variance inferred from metric distances among DNA haplotypes: Application to human mitochondrial DNA restriction data. Genetics 131:479-491.

Excoffier, L., G. Laval, and S. Schneider (2005). Arlequin ver. 3.0: An integrated software package for population genetics data analysis. Evolutionary Bioinformatics Online 1:47-50.

Finsch, O. (1901). Zosteropidae. Das Tierreich 15:46.

Flenley, J. R. (1998). Tropical forests under the climates of the last 30,000 years. Climatic Change 39:177-197.

Gathorne-Hardy, F. J., Syaukani, R. G. Davies, P. Eggleton, and D. T. Jones (2002). Quaternary rainforest refugia in south-east Asia: Using termites (Isoptera) as indicators. Biological Journal of the Linnean Society 75:453-466.

Gawin, D. F. (2007). Patterns of variation in the Mountain Blackeye (Chlorocharis emiliae) in selected mountain tops in Sabah and Sarawak, Malaysia. M.Sc. thesis, Universiti Malaysia Sarawak, Kota Samarahan, Sarawak, Malaysia. 
Gorog, A. J., M. H. Sinaga, and M. D. Engstrom (2004). Vicariance or dispersal? Historical biogeography of three Sunda shelf murine rodents (Maxomys surifer, Leopoldamys sabanus and Maxomys whiteheadi). Biological Journal of the Linnean Society 81:91-109.

Grubb, P. J. (1971). Interpretation of Massenerhebung effect on tropical mountains. Nature 229:44-45.

Grubb, P. J., and T. C. Whitmore (1966). A comparison of montane and lowland rain forest in Ecuador. II. The climate and its effects on the distribution and physiognomy of the forests. Journal of Ecology 54:303-333.

Hackett, S. J. (1996). Molecular phylogenetics and biogeography of tanagers in the genus Ramphocelus (Aves). Molecular Phylogenetics and Evolution 5:368-382.

Hanebuth, T., K. Stattegger, and P. M. Grootes (2000). Rapid flooding of the Sunda Shelf: A late-glacial sea-level record. Science 288:1033-1035.

Harris, R. B., M. D. Carling, and I. J. Lovette (2013). The influence of sampling design on species tree inference: A new relationship for the New World chickadees (Aves: Poecile). Evolution Early View. doi:10.1111/evo.12280

Harrisson, T. (1949). Explorations in central Borneo. The Geographical Journal 114:129-150.

Harrisson, T. (1955a). The Mountain Blackeye (Chlorocharis): Ecology and natural history. The Sarawak Museum Journal 6: 663-687.

Harrisson, T. (1955b). The Oxford University expedition to Sarawak, 1932. The Geographical Journal 82:385-406.

Harrisson, T. (1956). A new Mountain Black-eye (Chlorocharis) from North Borneo. The Sarawak Museum Journal 7:518-521.

Hartert, E. (1897). Mr. William Doherty's bird-collection from Celebes. Novitates Zoologicae 4:157.

Helm-Bychowski, K., and J. Cracraft (1993). Recovering phylogenetic signal from DNA sequences: Relationships within the corvine assemblage (class Aves) as inferred from complete sequences of the mitochondrial DNA cytochrome-b gene. Molecular Biology and Evolution 10:1196-1214.

Hosner, P. A., F. H. Sheldon, H. C. Lim, and R. G. Moyle (2010). Phylogeny and biogeography of the Asian trogons (Aves: Trogoniformes) inferred from nuclear and mitochondrial DNA sequences. Molecular Phylogenetics and Evolution 57:12191225.

Irham, M., E. Meijaard, and S. van Balen (2012). New information on the distribution of White-fronted Microhierax latifrons and Black-thighed Falconets M. fringillarius in Kalimantan, Indonesia. Forktail 28:162-163.

Iwanaga, H., K. M. Teshima, I. A. Khatab, N. Inomata, R. Finkeldey, I. Z. Siregar, U. J. Siregar, and A. E. Szmidt (2012). Population structure and demographic history of a tropical lowland rainforest tree species Shorea parvifolia (Dipterocarpaceae) from Southeastern Asia. Ecology and Evolution 2:1663-1675.

Johnson, K., and M. Sorenson (1998). Comparing molecular evolution in two mitochondrial protein coding genes (cytochrome $\mathrm{b}$ and ND2) in the dabbling ducks (Tribe: Anatini). Molecular Phylogenetics and Evolution 10:82-94.

Kamiya, K., K. Harada, M. M. Clyde, and A. L. Mohamed (2002). Genetic variation of Trigonobalanus verticillata, a primitive species of Fagaceae, in Malaysia revealed by chloroplast sequences and AFLP markers. Genes \& Genetic Systems 77: $177-186$.
Klicka, J., G. Voelker, and G. M. Spellman (2005). A molecular phylogenetic analysis of the "true thrushes" (Aves: Turdinae). Molecular Phylogenetics and Evolution 34:486-500.

Knowles, L. L. (2000). Tests of Pleistocene speciation in montane grasshoppers (genus Melanoplus) from the sky islands of western North America. Evolution 54:1337-1348.

Knowles, L. L. (2001). Did the Pleistocene glaciations promote divergence? Tests of explicit refugial models in montane grasshoppers. Molecular Ecology 10:691-701.

Lanyon, S., and J. Hall (1994). Reexamination of barbet monophyly using mitochondrial-DNA sequence data. The Auk 111:389-397.

Lee, P., D. Clayton, R. Griffiths, and R. Page (1996). Does behavior reflect phylogeny in swiftlets (Aves: Apodidae)? A test using cytochrome $b$ mitochondrial DNA sequences. Proceedings of the National Academy of Sciences of the United States of America 93:7091-7096.

Librado, P., and J. Rozas (2009). DnaSP v5: A software for comprehensive analysis of DNA polymorphism data. Bioinformatics 25:1451-1452.

Lim, H. C., M. A. Rahman, S. L. H. Lim, R. G. Moyle, and F. H. Sheldon (2011). Revisiting Wallace's haunt: Coalescent simulations and comparative niche modeling reveal historical mechanisms that promoted avian population divergence in the Malay Archipelago. Evolution 65:321-334.

Lim, H. C., and F. H. Sheldon (2011). Multilocus analysis of the evolutionary dynamics of rainforest bird populations in Southeast Asia. Molecular Ecology 20:3414-3438.

Lim, H. C., F. Zou, S. S. Taylor, B. D. Marks, R. G. Moyle, G. Voelker, and F. H. Sheldon (2010). Phylogeny of magpie-robins and shamas (Aves: Turdidae: Copsychus and Trichixos): Implications for island biogeography in Southeast Asia. Journal of Biogeography 37:1894-1906.

MacKinnon, K., G. Hatta, H. Halim, and A. Mangalik (1996). The Ecology of Kalimantan: Indonesian Borneo. Periplus Editions Ltd., Singapore.

Mann, C. F. (2008). The Birds of Borneo: An Annotated Checklist. British Ornithologists' Union and British Ornithologists' Club, Peterborough, United Kingdom.

McCormack, J. E., B. S. Bowen, and T. B. Smith (2008). Integrating paleoecology and genetics of bird populations in two sky island archipelagos. BMC Biology 6:28.

McDonald, J., and M. Kreitman (1991). Adaptive protein evolution at the adh locus in Drosophila. Nature 351:652-654.

Mees, G. F. (1954). A new white-eye from Borneo: Chlorocharis emiliae fusciceps, nov. subspec. Ardea 42:356-357.

Mees, G. F. (1955). Geographical and individual variation in Chlorocharis emiliae Sharpe. The Sarawak Museum Journal 6: 641-661.

Melo, M., B. H. Warren, and P. J. Jones (2011). Rapid parallel evolution of aberrant traits in the diversification of the Gulf of Guinea white-eyes (Aves, Zosteropidae). Molecular Ecology 20:4953-4967.

Moltesen, M., M. Irestedt, J. Fjeldså, P. G. P. Ericson, and K. A. Jønsson (2012). Molecular phylogeny of Chloropseidae and Irenidae-Cryptic species and biogeography. Molecular Phylogenetics and Evolution 65:903-914.

Morley, R. J. (2000). Origin and Evolution of Tropical Rain Forests. John Wiley \& Sons, New York, USA.

Moyle, R. G., C. E. Filardi, C. E. Smith, and J. Diamond (2009). Explosive Pleistocene diversification and hemispheric expan- 
sion of a "great speciator." Proceedings of the National Academy of Sciences of the United States of America 106: 1863-1868.

Moyle, R. G., P. A. Hosner, J. Nais, M. Lakim, and F. H. Sheldon (2008). Taxonomic status of the Kinabalu 'linchi' swiftlet. Bulletin of the British Ornithologists' Club 128:94-100.

Moyle, R. G., M. Schilthuizen, M. A. Rahman, and F. H. Sheldon (2005). Molecular phylogenetic analysis of the white-crowned forktail Enicurus leschenaulti in Borneo. Journal of Avian Biology 36:96-101.

Moyle, R. G., S. S. Taylor, C. H. Oliveros, H. C. Lim, C. L. Haines, M. A. Rahman, and F. H. Sheldon (2011). Diversification of an insular Southeast Asian genus: Phylogenetic relationships of the spiderhunters (Aves: Nectariniidae). The Auk 128:777788.

Myers, S. (2009). A Field Guide to the Birds of Borneo. New Holland Publishers, London, England.

Ohtani, M., T. Kondo, N. Tani, S. Ueno, L. S. Lee, K. K. S. Ng, N. Muhammad, R. Finkeldey, M. Na'iem, S. Indrioko, K. Kamiya, et al. (2013). Nuclear and chloroplast DNA phylogeography reveals Pleistocene divergence and subsequent secondary contact of two genetic lineages of the tropical rainforest tree species Shorea leprosula (Dipterocarpaceae) in South-East Asia. Molecular Ecology 22:2264-2279.

Phillipps, Q., and K. Phillipps (2011). Phillipps' Field Guide to the Birds of Borneo, Second Edition. John Beaufoy Publishing, Oxford, England.

Preme, A., and M. Heegaard (1988). A visit to Gunung Nyiut in West Kalimantan. Borneo Research Bulletin 20:162-166.

Ramji, M. F. S. (2010). Patterns of plumage colouration, genetic and morphological variation in mountain blackeye (Chlorocharis emiliae) from Malaysian Borneo. M.Sc. thesis, Universiti Malaysia Sarawak, Kota Samarakan, Sarawak, Malaysia.

Ramji, M. F. S., P. Y. Min, M. R. A. Rahman, and M. A. Rahman (2012a). Rediscovery of the enigmatic Mountain Black-eye, Chlorocharis emiliae Sharpe, 1888 (Passeriformes: Zosteropidae) from Mount Pueh, Sarawak. Tropical Natural History 12: 261-266.

Ramji, M. F. S., and M. A. Rahman (2011). Comparative temporal discouloration of dry museum specimens of mountain blackeye (Chlorocharis emiliae). Borneo Journal of Research Science Techniques 1:1-13.

Ramji, M. F. S., M. A. Rahman, and A. A. Tuen (2012b). Morphological variation of Mountain Blackeye (Chlorocharis emiliae) populations in Malaysian Borneo. Malaysian Applied Biology 41:1-10.

Sebastian, A. (2007). A preliminary investigation of the mammal and bird fauna of Gunung Arun, North Krayan, East Kalimantan, Republic of Indonesia. WWF-Indonesia, PHPA, and LIPI, Aonyx Environmental, Kuching, Malaysia.

Sheldon, F. H., C. E. Brown, M. A. Rahman, K. T. Guan, and R. G. Moyle (2013). Ornithology of the Kelabit Highlands of Sarawak, Malaysia. Raffles Bulletin of Zoology 61:1-27.

Sheldon, F. H., D. J. Lohman, H. C. Lim, F. Zou, S. M. Goodman, D. M. Prawiradilaga, K. Winker, T. M. Braile, and R. G. Moyle (2009). Phylogeography of the magpie-robin species complex (Aves: Turdidae: Copsychus) reveals a Philippine species, an interesting isolating barrier, and unusual dispersal patterns in the Indian Ocean and Southeast Asia. Journal of Biogeography 36:1070-1083.

Sheldon, F. H., R. G. Moyle, and J. Kennard (2001). Ornithology of Sabah: History, gazetteer, annotated checklist, and bibliography. Ornithological Monographs 52:1-285.

Sheldon, F. H., C. H. Oliveros, S. S. Taylor, B. McKay, H. C. Lim, M. A. Rahman, H. Mays, and R. G. Moyle (2012). Molecular phylogeny and insular biogeography of the lowland tailorbirds of Southeast Asia (Cisticolidae: Orthotomus). Molecular Phylogenetics and Evolution 65:54-63.

Smythies, B. E. (1957). An annotated checklist of the birds of Borneo. The Sarawak Museum Journal 7:523-818.

Smythies, B. E. (1960). The Birds of Borneo. Oliver and Boyd, London, England.

Smythies, B. E. (1999). The Birds of Borneo, 4th Edition. Natural History Publications (Borneo), Kota Kinabalu, Malaysia.

Sorenson, M. D., J. C. Ast, D. E. Dimcheff, T. Yuri, and D. P. Mindell (1999). Primers for a PCR-based approach to mitochondrial genome sequencing in birds and other vertebrates. Molecular Phylogenetics and Evolution 12:105-114.

Steinheimer, F. C. (1999). The Mountain Black-eye Chlorocharis emiliae (Zosteropidae) as a rhododendron flower visitor on Mt. Kinabalu, Sabah, Malaysia. Forktail 15:100-101.

Tajima, F. (1989). Statistical method for testing the neutral mutation hypothesis by DNA polymorphism. Genetics 123: 585-595.

Tamura, K., and M. Nei (1993). Estimation of the number of nucleotide substitutions in the control region of mitochondrial DNA in humans and chimpanzees. Molecular Biology and Evolution 10:512-526.

Tamura, K., D. Peterson, N. Peterson, G. Stecher, M. Nei, and S. Kumar (2011). MEGA5: Molecular evolutionary genetics analysis using maximum likelihood, evolutionary distance, and maximum parsimony methods. Molecular Biology and Evolution 28:2731-2739.

Teacher, A., and D. Griffiths (2011). HapStar: Automated haplotype network layout and visualisation. Molecular Ecology Resources 11:151-153.

Thomas, M. F. (2000). Late Quaternary environmental changes and the alluvial record in humid tropical environments. Quaternary International 72:23-36.

Voris, H. K. (2000). Maps of Pleistocene sea levels in Southeast Asia: Shorelines, river systems and time durations. Journal of Biogeography 27:1153-1167.

Warren, B. H., E. Bermingham, R. P. Prys-Jones, and C. Thebaud (2006). Immigration, species radiation and extinction in a highly diverse songbird lineage: White-eyes on Indian Ocean islands. Molecular Ecology 15:3769-3786.

Weir, J. T., and D. Schluter (2008). Calibrating the avian molecular clock. Molecular Ecology 17:2321-2328.

Whitehead, J. (1893). Exploration of Mount Kina Balu, North Borneo. Gurney and Jackson, London, England.

Whitmore, T. C. (1984). Tropical Rain Forests of the Far East. Clarendon Press, Oxford, England.

Wong, T. S. (2010). Of North Borneo birds and others: Mountain Blackeye-Borneo endemic. http://borneobirds.blogspot. com/2010_09_01_archive.html 